\title{
Membrane-delimited activation of muscarinic $K$ current by an albumin-associated factor in guinea-pig atrial myocytes
}

\author{
Moritz Bünemann, Lutz Pott \\ Institut für Physiologie, Ruhr-Universität Bochum, Universitätsstrasse 150, D-44780 Bochum, Germany \\ Received April 8, 1993/Received after revision June 1, 1993/Accepted July 1, 1993
}

\begin{abstract}
Atrial myocytes obtained by enzymatic perfusion of hearts from adult guinea-pigs and cultured for $0-14$ days were studied using different configurations of the patch-clamp technique. Activation of muscarinic $\mathrm{K}$ current $\left[I_{\mathrm{K}(\mathrm{ACh})}\right]$ in whole-cell voltage-clamp mode by strongly diluted sera from various sources could be mimicked by corresponding concentrations of albumin, but not by delipidated ("fatty-acid-free") samples of albumin. In cell-attached membrane patches activity of $I_{K(A C b)}$ channels was significantly higher than basal $I_{\mathrm{K}(\mathrm{ACh})}$ channel activity, if the pipette contained serum, whereas application of serum-containing solution to the cell outside the patch did not affect channel activity. In isolated inside-out membrane patches, strong $I_{\mathrm{K}(\mathrm{ACh})}$ activation by internal guanosine triphosphate (GTP, $5 \mu \mathrm{M}$ ) was observed if the pipette contained serum. If no activator was presented to the outer face of the membrane, only weak opening activity was observed during bath application of GTP. These results demonstrate that the serum factor which causes activation of $I_{\mathrm{K}(\mathrm{ACh})}$ is associated with albumin. Furthermore activation of $I_{\mathrm{K}(\mathrm{ACh})}$ by that factor proceeds analogous to $\mathrm{ACh}$ or adenosine, i. e. via a membrane-delimited receptor, G-protein, channel interaction.
\end{abstract}

Key words: Cardiac myocyte - Muscarinic K current - G-protein - Albumin - Serum

\section{Introduction}

Sera from different species and various suppliers have been described to exert acetylcholine-(ACh-)like effects in cardiac atrial and ventricular myocytes. These acute effects include activation of muscarinic $K$ current $\left[I_{\mathrm{K}(\mathrm{ACh})},[2]\right]$ and reduction of $\beta$-receptor stimulated $\mathrm{L}$ type $\mathrm{Ca}^{2+}$ current $\left(I_{C a}\right)$ via inhibition of $\beta$-receptor-sensi-

Correspondence to: L. Pott tive adenylyl cyclase [1]. Both actions can be identified at dilutions down to about $1: 10^{5}(\mathrm{v} / \mathrm{v})$, with half-maximal activity in the order of $1: 10^{3}$. In analogy to muscarinic-receptor-mediated events $[1,14,19,24]$ both actions of diluted sera are inhibited by pre-incubation of the myocytes with pertussis toxin, and thus are mediated by a defined class or type of G-protein.

It is well documented that $l_{\mathrm{K}(\mathrm{ACh})}$ channels are directly gated by interaction with such a G-protein, if ACh or ligands for various other receptors are used as activating agonists [5, 22], see [17] for review. In this regard, $I_{\mathrm{K}(\mathrm{ACn})}$ activation has been shown to proceed much faster than a receptor-mediated membrane effect which uses a second-messenger-dependent signalling pathway, such as, for example, $\beta$-adrenergic modulation of cardiac $L$ type $I_{\mathrm{Ca}}$ via activation of adenylyl cyclase [10].

Using a device for fast solution changes around a cell to be studied, onset and washout of serum-evoked $I_{\mathbf{K}(\mathrm{ACh})}$ were slower by at least 1 order of magnitude as compared to $\mathrm{ACh}$ as the activating ligand. Peak $I_{\mathrm{K}(\mathrm{ACb})}$ during serum superfusion was reached after tens of seconds up to $2 \mathrm{~min}$ as compared to several hundred milliseconds in the case of ACh. This suggests a different mechanism of channel gating, possibly involving additional steps leading from activation of the G-protein by GDP/GTP exchange to modification of the gating behaviour of the channel. Such an alternative mechanism has been suggested for $I_{\mathrm{K}(\mathrm{ACh})}$ activation by platelet activating factor (PAF [20], see Discussion).

In the present investigation we show that the active principle is associated with albumin. No activity, however, is found in fatty-acid-free (faf) albumin. Using the cell-attached and the inside-out configurations of the patch-clamp technique, the present investigation shows that: (i) activation of $I_{\mathrm{K}(\mathrm{ACb})}$ by the albumin-associated factor is membrane delimited, and (ii) that the velocity of activation of $I_{\mathrm{K}(\mathrm{ACb})}$ channels by this factor is as fast as with ACh, if it proceeds by application of GTP to the internal face of the membrane, with the activator being present at the outside. Our results suggest that activation 
of $I_{\mathrm{K}(\mathrm{ACh})}$ channels by the albumin-associated factor proceeds conventionally, i. e. via local interaction of the Gprotein subunit with the channel protein.

\section{Materials and methods}

Isolation and culture of atrial myocytes. The method of cell isolation and the conditions for long-term culture of atrial myocytes from hearts of adult guinea-pigs have been described in detail previously [3]. For the experiments cultured myocytes were used from day 0 (freshly isolated) to day 12 after isolation. The membrane capacitance of the cells ranged from 15 to $25 \mathrm{pF}$.

Solutions. For the measurements the culture medium was replaced by a solution containing $(\mathrm{mM}): \mathrm{NaCl} 120 ; \mathrm{KCl} \mathrm{20}, \mathrm{CaCl}_{2} 2.0$; $\mathrm{MgCl}_{2} 1.0 ; 4$-(2-hydroxyethyl)-1-piperazineethanesulphonic acid (HEPES)/KOH 10.0, pH 7.4. In whole-cell voltage-clamp experiments the solution for filling the patch-clamp pipettes and, thus internal dialysis of the cells contained $(\mathrm{mM}): \mathrm{K}$ aspartate $110 ; \mathrm{KCl}$ 20; MgATP 5.0; ethylenebis(oxonitrilo)tetraacetate (EGTA) 2.0; guanosine triphosphate (GTP) 0.01 ; HEPES/KOH 10.0, pH 7.4. For measurements in the cell-attached mode the pipette was filled with a solution of $150 \mathrm{mM} \mathrm{KCl}, 2 \mathrm{mM} \mathrm{CaCl}$, buffered with $10 \mathrm{mM}$ HEPES/KOH (to $\mathrm{pH}$ 7.4). The rationale for the compositions of these solutions was to measure $I_{\mathrm{K}(\mathrm{ACh})}$ negative to the equilibrium potential for $\mathbf{K}$ ions $\left(E_{\mathrm{E}}\right)$, i. e. as an inward current, since it has strong inwardly rectifying properties.

Current measurement. Membrane currents were measured under voltage-clamp by means of patch-clamp pipettes (whole-cell, cellattached and inside-out modes [9]). Pipettes were fabricated from borosilicate glass with filament (Clark, Pangbourne, UK) and were filled with one of the solutions listed above. The DC resistance of the filled pipettes ranged from 2 to $6 \mathrm{M} \Omega$. Current measurements were performed by means of a patch-clamp amplifier (List LM/ EPC 7). Signals were passed through an analog filter with a corner frequency of either $1 \mathrm{kHz}$ (whole-cell) or $3 \mathrm{kHz}$ (single-channel measurements) and were digitally stored on the hard-disc of an IBM compatible AT-computer equipped with an AD/DA board (DT 2821-F, Data Translation) for subsequent analysis. Experiments were performed at ambient temperature $\left(21-33^{\circ} \mathrm{C}\right)$.

Rapid superfusion of the cells for application and withdrawal of different solutions was performed by means of a solenoid-operated flow system that permitted switching between five different solutions. The solutions flowed through capillary tubes into a common outlet. The cell under study was continuously superfused at approximately $0.25 \mathrm{ml} / \mathrm{min}$ with a stream of solution of $200 \mu \mathrm{m}$ in diameter close to the outlet. The half-time of a change in concentration seen by the cell was determined as $200-600 \mathrm{~ms}$. Simultancously the culture dish was perfused at about $1 \mathrm{ml} / \mathrm{min}$ with standard solution throughout an experiment.

\section{Results}

In previous investigations the $\mathrm{EC}_{50}$ of horseserum (HS) for mimicking muscarinic effects in atrial myocytes was determined as about $1: 1000$. Potencies in the same order of magnitude were determined for different human sera, fetal calf serum (FCS, a commonly used supplement for cell culture media, Sigma F2268, Gibco, "heat inactivated", 01306290), and plasma (horse, Sigma P3016) [1, 2]. On a Sephadex column the $I_{\mathrm{K}(\mathrm{ACb})}$-activating factor in horse serum co-purified with the albumin fraction (MW $60-70 \mathrm{kDa}$ ). On the other hand, no activity was found in samples of purified albumins (Sigma A1887, Boeh-

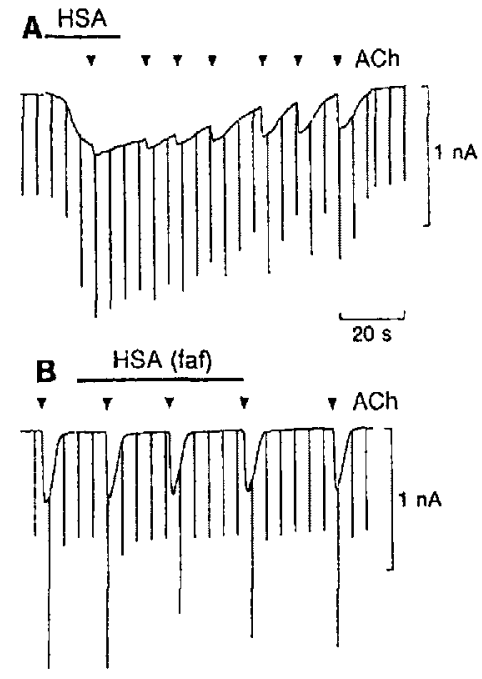

Fig. $1 \mathrm{~A}, \mathrm{~B}$. Activation of muscarinic $\mathrm{K}$ current $\left[I_{\mathrm{K}\left(\mathrm{A} \mathrm{C}_{2}\right)}\right]$ by human serum albumin (HSA). A ACh $\left(10^{-6} \mathrm{M}\right)$ was superfused as indicated by the arrowheads, HSA superfusion $\left(5.8 \times 10^{-6} \mathrm{M}\right)$ is indicated by the horizontal bar. The rapid downward deflections result from hyperpolarizing voltage steps to $-120 \mathrm{mV}$ which were applied in most experiments in order to control the access resistance. B Same conditions as in A. Fatty-acid-free HSA [HSA(faf), $5.8 \times 10^{-6} \mathrm{M}$ ] was superfused as indicated (A and $\mathbf{B}$ represent two different cells)

ringer Mannheim, Germany 1081489). As these products were of the grade "essentially fatty acid free"(faf) we re-investigated this problem by comparing faf and non-faf albumin from one manufacturer (Sigma A1887, A1653).

Figure $1 \mathrm{~A}$ illustrates that the effect of serum can be mimicked by an albumin which was not delipidated. A slowly developing and decaying inward $I_{\mathrm{K}(\mathrm{ACh})}$ is induced by supcrfusion with a solution containing human serum albumin (HSA, Sigma A1653) at a concentration of $5.8 \mu \mathrm{M}$.

Assuming a physiological albumin concentration in human serum of $579 \mu \mathrm{M}$, this corresponds to a 100 -fold dilution of serum. Figure $1 \mathrm{~B}$ is a representative example of a recording which demonstrates that delipidated (faf) albumin at the same concentration is inactive [HSA(faf), Sigma A1887; this product, according to the manufacturer is made from the above A1653 by charcoal treatment]. Whereas each cell that showed a clear response to ACh also was sensitive to serum $(n>100)$ or HSA $(n=11)$, a lack of an effect of HSA(faf) $(1: 100)$ was found in all five cells tested. As has been described previously for $I_{\mathrm{K}(\mathrm{ACb})}$ activation by serum, the current in the presence of non-faf albumin develops and decays 12 orders of magnitude more slowly than with $\mathrm{ACh}$ as activating agonist (Fig. $1 \mathrm{~A}$ ). A representative concentration/response curve determined for non-faf-HSA is graphed in Fig. 2. The $\mathrm{EC}_{50}$ used to fit the data points is $1.4 \times 10^{-6} \mathrm{M}$. This corresponds to a 414 -fold dilution of serum.

For HS an $\mathrm{EC}_{50}$ of about $1: 1000$ has been determined previously. Considering different species, possible variations among different charges etc, the $I_{\mathrm{K}(\mathrm{ACh})^{-}}$ 


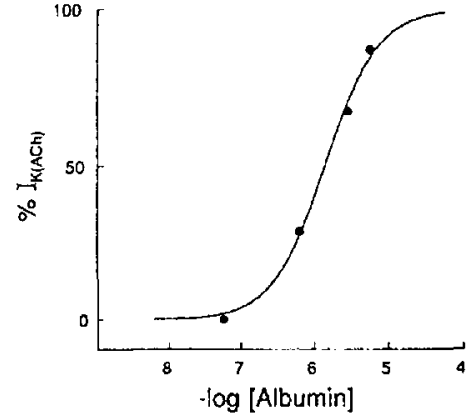

Fig. 2. Dependence of $I_{\mathrm{K}(\mathrm{ACh})}$ on HSA concentration. $I_{\left.\mathrm{x}_{(A \mathrm{C})}\right)}$ relative to the current evoked by $\mathrm{ACh}\left(10^{-6} \mathrm{M}\right)$ is plotted against the concentration of HSA on a logarithmic scale. The curve was fitted using simple saturation kinetics $\left(n_{\mathrm{H}}=1.2 ; K_{\mathrm{D}}=1.4 \times 10^{-6} \mathrm{M}\right)$; data from one representative cell

activating principle in serum seems to be entirely associated with albumin. This observation, and the finding that delipidation of albumin removes the $I_{\mathrm{K}(\mathrm{ACb})}$-activating principle, point to analogous findings with Xenopus oocytes, where a serum-component triggers an inositol 1,4,5-trisphosphate (InsP $P_{3}$ ) response, normally controlled by a muscarinic receptor [26], and with PC12 cells, in which $\mathrm{Ca}^{2+}$ signals and growth responses can be evoked by a serum factor $[7,8]$. These authors managed to identify the active principle as lyosphosphatidic acids (LPA) that are firmly bound to albumin [25, 27], see also [6]. Purified LPAs that were highly active in the oocyte system, which were kindly provided to us by Dr. Gabor Tigyi, however did not evoke $I_{\mathrm{K}(\mathrm{ACO})}$ in atrial myocytes.

The slow time course of $I_{\mathrm{K}(\mathrm{ACh})}$ induced by the albumin-associated factor, as compared to $\mathrm{ACh}$ as activator of this current, is similar to receptor-evoked cellular responses that involve the formation of second-messengercoupled signalling cascades (compare [10] for the time course of $\beta$-receptor modulated $I_{\mathrm{Ca}}$ in cardiac muscle).

In order to obtain further information on the signalling pathway initiated by the albumin-associated factor, we performed measurements of $I_{K(\mathrm{ACh})}$ channels in the cell-attached and inside-out configurations of the patchclamp technique. In the cell-attached mode a membrane channel under the mouth of the pipette is accessible to signals from outside this area only if these can diffuse in the cytosol. Activation of receptor mechanisms outside the membrane patch under study (i. e. in virtually the entire cell membrane) that do not produce diffusible intracellular signalling molecules should fail to modify a target in the patch. As the single $I_{\mathrm{K}(\mathrm{ACh})}$ channel displays strong inward-rectifying properties, a high-K solution was used for filling the pipettes, whereas the extracellular solution contained $20 \mathrm{mM} \mathrm{K}$ in order to stabilize the membrane potential of the cell at about $-50 \mathrm{mV}$.

In virtually all patches open events of $I_{\mathrm{K}(\mathrm{AC})}$ channels were identified by the following criteria: (i) unit conductance of $45-50 \mathrm{pS}$ in symmetrical $\left[\mathrm{K}^{+}\right]$(e. $\mathrm{g}$. [14]) and (ii) mean open time duration of less than $1 \mathrm{~ms}$. In less than $10 \%$ of the recordings openings of a $\mathrm{K}$ channel with about half the unit conductance of $I_{\mathrm{K}(\mathrm{ACh})}$ chan-

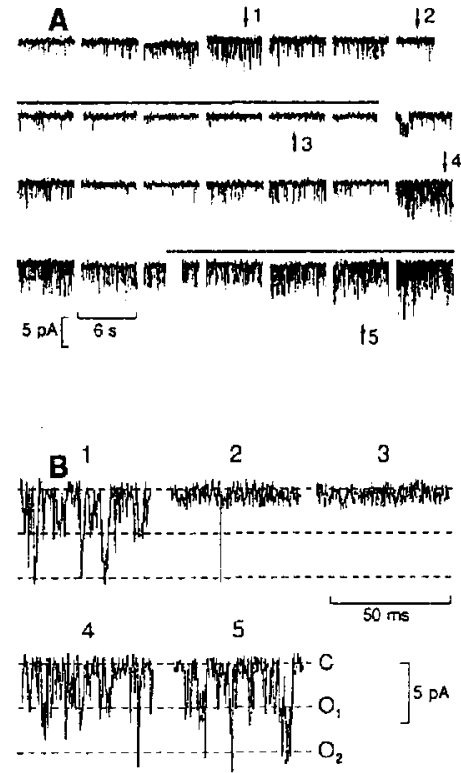

Fig. 3. A Cell-attached recording of basal $I_{\mathrm{K}(\mathrm{ACC})}$ activity and during superfusion of the cell with serum-containing solution (HS, 1:100, marked by the horizontal bars). B Sections of the current recordings traced in $\mathbf{A}$ at higher temporal resolution and gain. The dashed lines, drawn by eye, denoted closed $(C)$, one channel open $\left(O_{1}\right)$, and two channels open $\left(O_{2}\right)$. Voltage across the patch in this figure and Fig. 4 was resting potential (about $-50 \mathrm{mV}$ ) plus pipette potential $(+40 \mathrm{mV})$ resulting in about $90 \mathrm{mV}$ driving force for $\mathrm{K}^{+}$

nels and much longer openings were detected, which are likely to represent $I_{\mathrm{K} 1}$ channels.

One problem that was encountered in the cell-attached recordings was the extreme temporal variation of channel activity in a given membrane patch. A typical example of this behaviour is illustrated in Fig. 3. Spontaneous, i. e. agonist-independent opening activity, which is an intrinsic property of this channel species, caused by agonist-independent G-protein and channel interaction $[11,21]$, has been recorded starting about $5 \mathrm{~s}$ after formation of the seal. The figure depicts a sequence of traces, each corresponding to $6 \mathrm{~s}$, interrupted by periods of $12 \mathrm{~s}$, i. e. the entire recording covers a period of time of about $8 \mathrm{~min}$. With and without the activator in the extracellular solution traces with seconds of virtually zero activity can be found, but also traces displaying two, or very rarely three simultaneous openings. In three experiments of this type, opening activity was analysed by integrating ten sequential current traces lasting $6 \mathrm{~s}$, in the absence and the presence of the activator in the extracellular solution outside the patch. The results are summarized in Fig. 4. In two measurements no significant change of opening activity was found, whereas in the third cell a highly significant decrease was calculated. From the data shown in the previous figure it seems very likely, however, that this decrease results from the slow temporal variation of basal channel activity. In Fig. 5 we compared cell-attached channel activity and macroscopic (whole-cell) current recorded from the same cell. In the original traces of channel ac- 


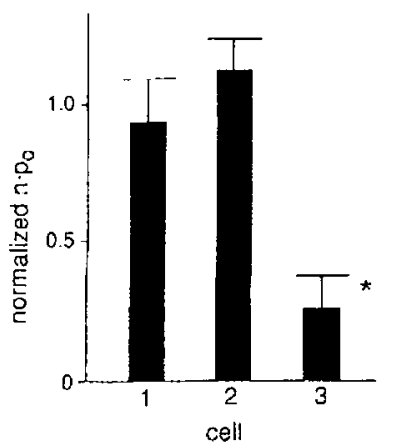

Fig. 4. Effect of superfusion of three different cells with HS $(1: 100)$ on integrated channel activity measured in the cell-attached mode. For each bar 10 sequential traces of $6 \mathrm{~s}$ in duration were electronically integrated and normalized to the mean value in the control condition, $i$. e. without HS in the superfusate. Mean values \pm SEM; activity in cell 3 was significantly different from $1(P<0.005)$

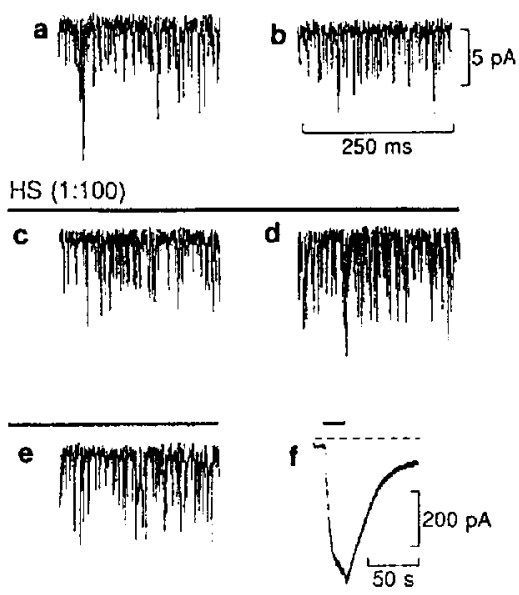

Fig. 5 a-f. Comparison of $I_{\mathrm{K}(\mathrm{ACC})}$ recorded in the cell-attached mode $(\mathbf{a}-\mathbf{c})$, and in the whole-cell mode (f). The cell-attached recordings $a$ and $b$ are sample traces of $250 \mathrm{~ms}$ in duration obtained $10 \mathrm{~s}$ and $5 \mathrm{~s}$ before superfusion of the cell with HS $(1: 100)$. c-e Traces were recorded 10,20 and $30 \mathrm{~s}$ after starting superfusion of the cell with HS. In order to get into the whole-cell mode, the membranc under the tip of the pipette was destroyed by a suction pulse after recording cell-attached activity. Horizontal bar denotes superfusion with HS, dashed line represents zero current

tivity recorded at various times before and during superfusion of the cell with HS $(1: 100)$ no obvious effect can be seen. It cannot be completely excluded that an effect is blunted by superimposed slow variation of basal activity. In the whole-cell configuration the holding current (at $-70 \mathrm{mV}$ ) was $25 \mathrm{pA}$. Superfusion of the cell with HS resulted in an inward current of $530 \mathrm{pA}$.

Assuming the holding current to represent mainly the basal activity of $I_{\mathrm{K}(\mathrm{ACC})}$, serum caused a more than 20 fold increase of this current. Although both recording conditions are not fully comparable, because of different $\mathrm{K}$ and electrical gradients, a dramatic effect on the current traces recorded from cell-attached patches should be seen, if activation via a cytosolic pathway were possible.

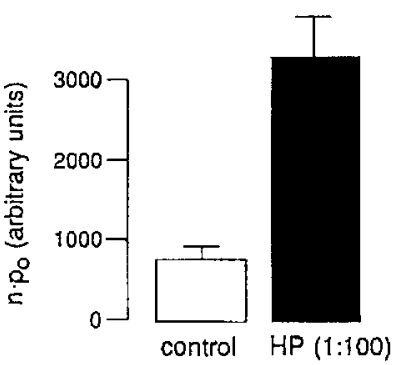

Fig. 6. Effect of horse plasma (HP, Sigma P3016, 1:100) in the pipette solution on channel activity in the cell-attached mode. Five cells in either condition ( \pm plasma) were studied. For each measurement 10 sequential traces, each $6 \mathrm{~s}$ in duration, were integrated. Evaluation of data in each case started within $30 \mathrm{~s}$ after gigaohm seal formation

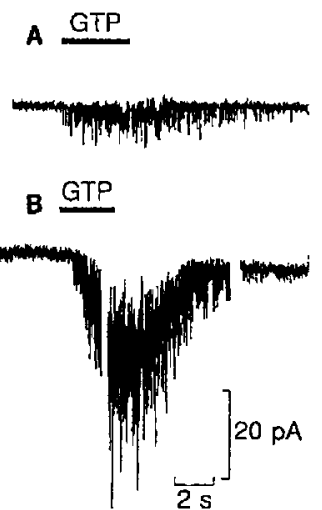

Fig. 7 A, B. Representative traces for the effects GTP-containing solution $(5 \mu \mathrm{M})$ on channel activity recorded in the inside-out configuration. A No activator was present in pipette solution; B pipette solution contained HS $(1: 100)$. GTP was applied as indicated by the horizontal bar. Voltage across the patch was $-70 \mathrm{mV}$

If in the cell-attached mode the pipette filling solution was supplemented with the activating compound, a significantly higher opening activity as compared to control solution was observed. This is illustrated in Fig. 6 which represents pooled data from five measurements in each condition. Horse plasma (HP, 1:100) was used as activator in this series. A significantly higher opening activity was found if the activator was present in the pipette solution, although the difference is smaller than one would expect from the result illustrated in Fig. 5.

With an activator present in the pipette solution, integrated channel current tends to be underestimated, because the baseline for the integral is set to the lowest level of current observed during that period. If a large number of channels is simultaneously active, the true baseline (i. e. all channels closed) sometimes is never reached during a recording (compare Fig. 7).

One of the crucial findings that proved the membrane-delimited, G-protein-mediated control of $I_{\mathrm{K}(\mathrm{ACh})}$ by the muscarinic receptor, was the sensitivity of the channel in inside-out, cell-free membrane patches to GTP applied to the internal face of the membrane [14]. In experiments using the inside-out configuration, massive channel activity was elicited upon changing from GTP- 
free to GTP-containing ( $5 \mu \mathrm{M})$ bathing solution. A typical result is illustrated in Fig. 7. After isolation of the patch and exposure to the GTP-free (internal) solution it took several seconds until opening activity completely ceased.

In agreement with previous studies using $\mathrm{ACh}$ as activating ligand in the pipette, rapid application of GTP to the internal face of the membrane resulted in a reversible massive activation of $I_{\mathrm{K}(\mathrm{ACh})}$ (Fig. 7B), whereas under otherwise identical conditions but without an activator in the pipette solution much less channel activity was recorded. From three measurements without an activator in the pipette the recording with the maximum of opening activity is traced in Fig. $7 \mathrm{~A}$.

\section{Discussion}

Cardiac $I_{\mathrm{K}(\mathrm{ACh})}$ is the prototype of a G-protein-gated ion channel, see [17] for review. Although this has first been demonstrated convincingly a couple of years ago $[5,22]$, it is still a controversial matter as to which subunit of the heterotrimeric G-protein is the final activator of the $I_{\mathrm{K}(\mathrm{ACh})}$ channel $[17,28]$.

Apart from the vagal transmitter $\mathrm{ACh}$, a number of ligands for other receptors have been described as potential activators of $I_{\mathrm{K}(\mathrm{ACh})}$, such as adenosine $[4,15]$, calcitonin gene-related peptide [12], PAF [20], $\alpha$-receptor agonists [16], somatostatin [18] and endothelin [13]. For $\mathrm{PAF}$ and the $\alpha$-receptor agonist phenylephrine a different mechanism of modulating $I_{\mathrm{K}(\mathrm{ACh})}$ channel activity has been proposed $[16,20,23]$. These authors suggested that arachidonic acid metabolites, formed by lipoxygenase, serve as activators of the $G$-protein $\left(G_{j}\right.$ or $\left.G_{K}\right)$, resulting in opening of the $I_{\mathrm{K}(\mathrm{ACb})}$ channel. This pathway differs from the "conventional" one, in that it is not membrane delimited.

In a previous investigation, from the lack of an effect of muscarinic and purinergic receptor antagonists, these receptors have been excluded from involvement in activation of $I_{\mathrm{K}(\mathrm{ACh})}$ by serum or the albumin-associated activating principle, respectively. From the finding that serum exerts $50 \%$ of its maximal effect in an approximately 1000 -fold dilution, a contribution of regulatory peptides to the effect of serum has been rendered unlikely [2]. Here we show that the activating factor is associated with albumin. This finding and the obvious lipid nature of the active principle seem to be analogous to the findings in Xenopus oocytes and neuroblastoma cells $[7,25]$. The lack of an effect of LPAs that were active in those systems, however, suggests that there might be different lipids bound to albumin, which turn on various signal transduction pathways in different cells.

The slow onset of the serum-evoked $I_{\mathrm{K}(\mathrm{ACh})}$ activation as compared to the effect of ACh points to some difference in the signal transduction pathways that finally cause opening of the $\mathrm{K}$ channel. Two major findings clearly show that the albumin-associated factor activates $I_{\mathrm{K}(\mathrm{ACh})}$ "conventionally", i. e. via local interaction with an activated G-protein: (i) in cell-attached patches no activation of $I_{\mathrm{K}(\mathrm{ACh})}$ channels occurs from the membrane outside the patch, and (ii) application of GTP to the internal face of an excised membrane patch, the original extracellular face of which is exposed to serum, results in rapid and reversible activation of $I_{\mathrm{K}(\mathrm{ACB})}$. Thus, the slow rate of $I_{\mathrm{K}(\mathrm{ACh})}$ activation by the albumin-associated activator is likely to result from a reaction upstream to $\mathrm{G}_{\mathrm{K}}$ channel interaction.

The final nature of the albumin-associated factor remains to be determined. Furthermore it has to be investigated whether there is a physiological role of this factor which, if active in the intact organism, would saturate the mechanisms of vagal regulation of the heart. As FCS, which is used as a supplement in many cell culture applications, also contains the factor, and even certain serum replacements, such as Nutridoma (Boehringer Mannheim), its acute and long-term effects on various types of cells in culture should be investigated.

Acknowledgement. This work was supported by the Deutsche Forschungsgemeinschaft (Po 212-6/1).

\section{References}

1. Banach K, Bünemann M, Hüser J, Pott L (1993) Serum contains a potent factor that decreases $\beta$-adrenergic receptorstimulated $\mathrm{L}$-type $\mathrm{Ca}^{2+}$ current in cardiac myocytes. Pflügers Arch $423: 245-250$

2. Banach K, Hüser J, Lipp P, Wellner MC, Pott L (1993) Activation of muscarinic $\mathrm{K}^{+}$current in guinea-pig atrial myocytes by a serum factor. J Physiol (Lond) 461:263-281

3. Bechem M, Pott L, Rennebaum H (1983) Atrial muscle cells from hearts of adult guinea-pigs in culture: a ncw preparation for cardiac cellular electrophysiology. Eur J Cell Biol $31: 366-369$

4. Belardinelli L, Isenberg G (1983) Isolated atrial myocytes: adenosine and acetylcholine increase potassium conductance. Am J Physiol 224:H734-H737

5. Breitwieser GE, Szabo G (1985) Uncoupling of cardiac muscarinic and $\beta$-adrenergic receptors from ion channels by a guanine nucleotide analogue. Nature 317:538-540

6. Durieux ME, Salafranca MN, Lynch KR, Moorman JR (1992) Lysophosphatidic acid induces a pertussis-toxin-sensitive $\mathrm{Ca}^{2+}$-activated $\mathrm{Cl}$ current in Xenopus laevis oocytes. Am J Physiol 263:C896-C900

7. Dyer D, Tigyi G, Miledi R (1992) The effect of active serum albumin on PC12 cells: $I$. Neurite retraction and activation of the phosphoinositide second messenger system. Mol Brain Res 14:293-301

8. Dycr D, Tigyi G, Miledi R (1992) The effect of active serum albumin on PC12 cells: II. Intracellular $\mathrm{Ca}^{2+}$ transients and their role in neurite retraction. Mol Brain Res 14:302-309

9. Hamill OP, Marty A, Neher E, Sakmann B, Sigworth FJ (1981) Improved patch-clamp techniques for high-resolution current recordings from cells and cell-free membrane patches. Pflügers Arch 391: 85-100

10. Hartzell HC, Méry P-F, Fischmeister R, Szabo G (1991) Sympathetic regulation of cardiac calcium current is due $\mathrm{cx}$ clusively to CAMP-dependent phosphorylation. Nature 351:573-576

11. Kaibara M, Nakajima 'T, Irisawa H, Giles W (1991) Regulation of spontaneous opening of muscarinic $\mathrm{K}^{+}$channels in rabbit atrium. J Physiol (Lond) 433:589-613

12. Kim D (1991) Calcitonin-gene-related peptide activates the muscarinic-receptor gated $\mathrm{K}^{+}$current in atrial cells. Pflügers Arch 418:338-345 
13. Kim D (1991) Endothelin activation of an inwardly rectifying $\mathrm{K}^{+}$current in atrial cells. Circ Res 69:250-255

14. Kurachi Y, Nakajima T, Sugimoto T (1986) Acetylcholine activation of $K$ channels in cell-free membrane of atrial cells. Am J Physiol 251:H681-H684

15. Kurachi Y, Nakajima T, Sugimoto $T$ (1986) On the mechanism of activation of muscarinic $\mathrm{K}^{+}$channels by adenosine in isolated atrial cells: involvement of GTP-binding proteins. Pflügers Arch 407: 264-274

16. Kurachi $Y$, Ito H, Sugimoto T, Shimizu T, Miki I, Ui M (1989) $a$-Adrenergic activation of the muscarinic $\mathrm{K}^{+}$channel is ediated by arachidonic acid metabolites. Pflügers Arch 414: $102-104$

17. Kurachi Y, Tung RT, Ito H, Nakajima T (1992) G protein activation of cardiac muscarinic $\mathrm{K}^{+}$channels. Prog Neurobiol $39: 229-246$

18. Lewis DL, Clapham DE (1989) Somatostatin activates an inwardly rectifying $\mathrm{K}^{+}$channel in neonatal rat atrial cells. Pflügers Arch 414: 492-494

19. Nakajima T, Wu S, Irisawa H, Giles W (1990) Mechanism of acetylcholine-induced inhibition of $\mathrm{Ca}$ curtent in bullfrog atrial myocytes. J Gen Phyisol 96: 865-885

20. Nakajima T, Sugimoto T, Kurachi Y (1991) Platelet-activating factor activates cardiac $G_{\mathrm{x}}$ via arachidonic acid metabolites. FEBS Lett $289: 239-243$

21. Okabe K, Yatani A, Brown AM (1991) The nature and origin of spontaneous noise in $\mathrm{G}$ protein-gated ion channels. J Gen Physiol 97:1279-1293
22. Pfaffinger PJ, Martin JM, Hunter DD, Nathanson NM, Hille B (1985) GTP-binding proteins couple cardiac muscarinic receptors to a K channel. Nature 317:536-538

23. Scherer RW, Breitwieser GE (1990) Arachidonic acid metabolites alter $G$ protein-mediated signal transduction in heart. Effects of muscarinic $\mathrm{K}^{+}$channels. J Gen Physiol 96:735755

24. Sorota S, Tsuji Y, Tajima T, Pappano AJ (1985) Pertussis toxin treatment blocks hyperpolarization by muscarinic agonists in chick atrium. Circ Res 57:748-758

25. Tigyi G, Miledi R (1992) Lysophosphatidates bound to serum albumin activate membrane currents in Xenopus oocytes and neurite retraction in PC12 pheochromocytoma cells. J Biol Chem 267:21360-21367

26. Tigyi G, Dyer D, Matute C, Miledi R (1990) A serum factor that activates the phosphatidylinositol phosphate signaling system in Xenopus oocytes. Proc Natl Acad Sci USA $87: 1521-1525$

27. Tigyi G, Henschen A, Miledi R (1991) A factor that activates oscillatory chloride currents in Xenopus oocytes copurifies with a subfraction of serum albumin. J Biol Chem 266: $20602-20609$

28. Yatani A, Okabe K. Birnbaumer L, Brown AM (1990) Detergents, dimeric $G \beta \gamma$, and eicosanoid pathways to muscarinic atrial $\mathrm{K}^{+}$channels. Am J Physiol 258:H1507-H1514 